\title{
Micronutrient deficiency in critical illness: an invisible foe?
}

\author{
Michael P. Casaer ${ }^{* *}$ and Rinaldo Bellomo 2,3
}

๑ 2019 Springer-Verlag GmbH Germany, part of Springer Nature

In critical illness, clinical features such as encephalopathy, muscle weakness, peripheral neuropathy, skin and mucosal lesions, and protracted organ dysfunction dominate the clinical picture (Fig. 1) Micronutrient deficiencies-reviewed in this viewpoint article-might contribute to this clinical phenotype and may, moreover, compromise acute outcome.

\section{Preventing refeeding-related morbidity and mortality}

Vitamin B1 (thiamine) is a key co-factor in substrate oxidation. Thus, thiamine deficiency affects major constant energy-dependent organs such as the heart (wet beriberi) or the brain (Wernicke's and Korsakoff's syndrome) [1]. Deficiency risk factors (e.g., diuretics, continuous renal replacement therapy (CRRT), and inadequate premorbid intake) are common in the ICU and body stores are low. Low thiamine plasma levels have been reported in ICU, but real-time monitoring is currently impossible. Clinically, thiamine depletion may only manifest itself when feeding is initiated. This "refeeding syndrome" is easily overlooked as it resembles the clinical phenotype of critical illness [1]. Moreover, this syndrome likely involves other biochemical abnormalities beyond thiamine deficiency [2]. In patients who, upon initiation of artificial nutrition, develop a significant decrease in serum phosphate levels and/or hypophosphatemia, temporary caloric restriction dramatically increased survival in a multicenter randomized-controlled trial (RCT) involving more than 400 patients [2], even though phosphate was

\footnotetext{
*Correspondence: Michael.casaer@uzleuven.be

${ }^{1}$ The Clinical Department and Laboratory of Intensive Care Medicine, University Hospitals Leuven (UZLeuven), Herestraat 49, 3000 Leuven, Belgium

Full author information is available at the end of the article
}

adequately repleted in both study arms. An observational study confirmed this pattern. Moreover, at-risk patients could not be identified based on ICU-admission characteristics [3]. Even with limited evidence, given the potential lethal consequences, monitoring and supplementing phosphate, restricting early nutrient administration, and providing ample doses of thiamine (>100 mg/day) appear prudent.

\section{Vitamin C and vitamin D repletion}

Vitamin $C$, an electron donor, plays an important role as antioxidant, and co-factor for multiple enzymes. During critical illness and particularly sepsis, reduced intake and increased oxidation can lower vitamin $\mathrm{C}$ levels, leading to free radical excess and, consequently, loss of endothelial nitric oxide synthase function [4]. This notion has inspired the hypothetical concept of high consumption and relative vitamin $C$ deficiency with the implied need to deliver pharmacologic doses (6 g/day) [4]. However, studies so far have been small or partly retrospective and the aggregated results of three RCT's evaluating vitamin $\mathrm{C}$ repletion in ICU have not generated conclusive results [5].

The vitamin D receptor impacts gene transcription in many organs and tissues, and its effects stretch far beyond calcium homeostasis and skeletal integrity to the cardiovascular system, immunity, and inflammation [6]. At ICU admission, more than $50 \%$ of critically ill patients have low 25-hydroxyvitamin D levels and $24 \%$ have very low levels [7]. Such low levels do not recover during ICU stay and are inversely associated with recovery and survival [8]. They have been attributed to lower premorbid intake, reduced renal conversion, lower levels of the circulating binding protein, and reduced hepatic production, exposure to sunlight and enteral intake [7]. Aggregating data from three RCTs did not reveal survival benefit with vitamin D repletion [5]. The VITDAL-RCT

\section{Springer}




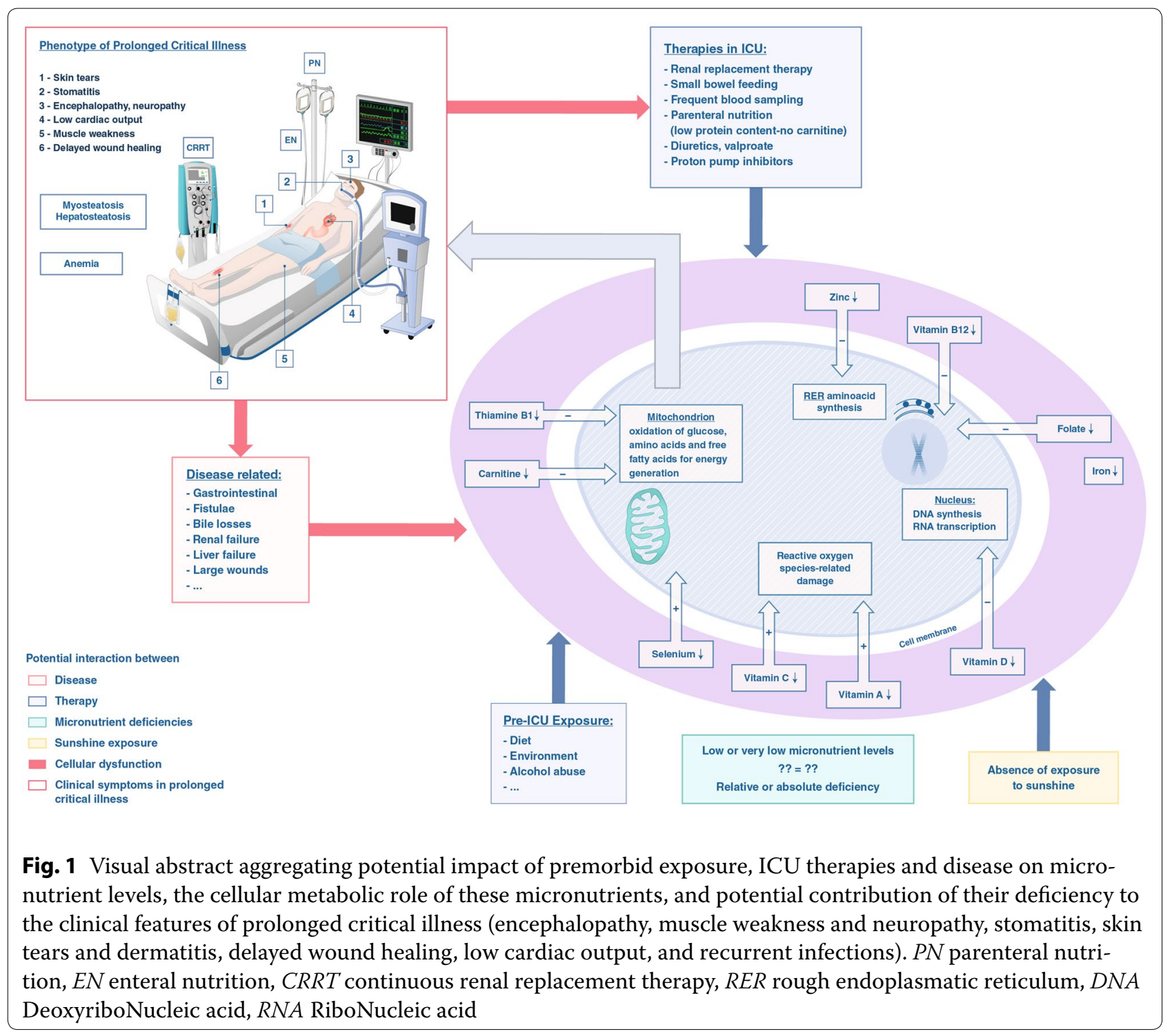

generated the hypothesis that correction of very low levels may increase survival [8]. On-going RCT's will provide a better understanding of whether low vitamin $C$ or $\mathrm{D}$ levels are morbidity- or mortality-causing deficiencies, epiphenomena, an adaptive response to severe illness, or a combination of any of these (Table 1 ) $[8,9]$.

\section{Vitamin B12, folate, zinc, and carnitine}

Vitamin B12 supports DNA synthesis and macronutrient metabolism, in particular L-methylmalonyl-CoA and homocysteine pathways [10]. Upper gastric surgery or small bowel feeding and, possibly, proton pump inhibitors may hamper vitamin B12 absorption [10]. Folate, a carbon-transferring co-factor, is also crucial to nucleic and amino acid synthesis [10]. Low levels are common in ICU, especially in the setting of alcoholism, hemolysis, malignancy, drugs like methotrexate and trimethoprim, and CRRT [11]. Clinically, Vitamin B12 or folate deficiency could be easily overlooked as their hallmark, megaloblastic anemia, may not develop in the iron and erythropoietin-deficient ICU context. Plasma levels are unreliable. Unexplained cognitive changes or clinical evidence suggestive of demyelination may thus be the first sign for B12 deficiency [10], a suspicion that can be confirmed by increased homocysteine and methylmalonyl-CoA concentrations. Thrombocytopenia or leukopenia may suggest folate deficiency. Given the difficult clinical and laboratory diagnosis for both deficiencies, prophylactic administration may provide a cost-effective alternative. In a small RCT, parenteral folate at $5 \mathrm{mg} /$ day appeared safe [12]. 
Table 1 Key multicenter randomized controlled trials of vitamin C and vitamin D in critical illness

\begin{tabular}{|c|c|c|c|c|c|}
\hline NCT number & Country & $\begin{array}{l}\text { Number } \\
\text { of patients }\end{array}$ & Condition & Primary outcome & Design \\
\hline NCT03680274 & Canada & 800 & Sepsis & $\begin{array}{l}\text { Mortality or persistent organ } \\
\text { dysfunction }\end{array}$ & $\begin{array}{l}\text { Double-blind-high-dose vitamin } \\
\text { C }\end{array}$ \\
\hline NCT 03509350 & USA & 2000 & Sepsis & $\begin{array}{l}\text { Vasopressor and ventilator-free } \\
\text { days }\end{array}$ & $\begin{array}{l}\text { Double-blind-high-dose vitamin } \\
\text { C+B1 and hydrocortisone }\end{array}$ \\
\hline NCT 03333278 & ANZ & 216 & Septic shock & Duration of vasopressor support & $\begin{array}{l}\text { Single-blind high-dose vitamin } \\
\text { C+B1 and hydrocortisone }\end{array}$ \\
\hline NCT $02106975^{* *}$ & USA & 170 & Septic ALI & SOFA score & $\begin{array}{l}\text { Double-blind-high-dose vitamin } \\
\text { C }\end{array}$ \\
\hline NCT 03389555 & USA & 200 & Sepsis & SOFA score & $\begin{array}{l}\text { Double-blind-high-dose vitamin } \\
\text { C+B1 and hydrocortisone }\end{array}$ \\
\hline NCT 03188796 & $\begin{array}{l}\text { Austria and Belgium (other } \\
\text { European ICU's are in prepa- } \\
\text { ration) }\end{array}$ & 2400 & $\begin{array}{l}\text { ICU patients } \\
\text { antici- } \\
\text { pated to } \\
\text { stay }>48 \mathrm{~h}\end{array}$ & Mortality at 28 days & $\begin{array}{l}\text { Double-blind-High-dose vitamin } \\
\text { D }\end{array}$ \\
\hline NCT03096314 & USA & 1360 & $\begin{array}{l}\text { Patients } \\
\text { planned for } \\
\text { admission } \\
\text { to the ICU }\end{array}$ & Landmark mortality on day 90 & High-dose vitamin D \\
\hline
\end{tabular}

Only multicenter studies are included with $>100$ patients randomized or expected to be randomized

ANZ Australia and New Zealand

**Only studies currently recruiting or completed

Zinc is a co-factor in DNA synthesis and RNA transcription [13]. Adequate levels depend on precisely regulated intake and excretion [14]. Intake may be inadequate in vegetarians or alcoholics, and may provoke immune dysfunction, hypogonadism, acrodermatitis, and growth disorders [13, 14]. Urinary and cutaneous losses in burns, trauma and sepsis, CRRT, and biliary losses may affect zinc homeostasis [14]. Four studies evaluating repletion in different doses or compared with placebo in non-selected ICU patients found no effect on mortality [5]. High serum copper concentrations or a positive clinical response to empirical treatment may be valuable alternatives to measuring serum zinc concentrations, the latter potentially reflecting redistribution $[14,15]$.

Carnitine depletion hampers the mitochondrial carnitine/palmitoyl shuttle, causing impaired oxidation of long-chain fatty acids and mitochondrial energetic dysfunction [16]. In patients with prolonged critical illness, liver and kidney dysfunction, reduced amino acid, and vitamin $C$ intake, specific drugs (e.g., valproate) and CRRT may cause deficiency. Unexplained muscle weakness, cardiac failure, or hypertriglyceridemia should trigger clinical suspicion, but uncertainty regarding the ratio of tissue-to-plasma levels complicates confirmation. Interventional trials in ICU have been inconclusive and so far focused on early blood level-unadjusted administration [17].

\section{Conclusion}

Our lack of knowledge of micronutrient pathophysiology and requirements during critical illness is striking. Based on the very limited evidence available today, we suggest clinicians to:

1. Prevent refeeding syndrome and, in case it develops, react by restricting caloric intake with slow increase over 5 days, while phosphate is replenished and higher dose ( $>100$ or $200 \mathrm{mg}$ ) thiamine administered in patients at risk of Wernicke's encephalopathy.

2. Systematically consider the possibility of micronutrient deficiency (the "invisible foe") in critically ill patients.

3. Guarantee provision of at least dietary reference intakes of micronutrients in critical illness.

4. Consider additional repletion of vitamin $\mathrm{C}$, vitamin D, B12, folate, zinc, and carnitine in high-risk patients.

Beyond the above principles, several trials of pharmacologic vitamin repletion (esp. vitamin C, thiamine, and vitamin D) are in progress and clinicians should carefully follow the literature for novel developments (Table 1). Moreover, estimates of the potential impact of deficiencies could be improved by concurrent assessment of serum or tissue micronutrient levels in RCTs of other therapies that might affect their levels (Fig. 1). Finally, the cost-effectiveness of targeted 
detection-correction versus empirical higher dose administration should be considered.

\author{
Author details \\ ${ }^{1}$ The Clinical Department and Laboratory of Intensive Care Medicine, Uni- \\ versity Hospitals Leuven (UZLeuven), Herestraat 49, 3000 Leuven, Belgium. \\ ${ }^{2}$ Centre for Integrated Critical Care, School of Medicine, The University of Mel- \\ bourne, Melbourne, Australia. ${ }^{3}$ Australian and New Zealand Intensive Care \\ Research Centre, School of Public Health and Preventive Medicine, Monash \\ University, Melbourne, Australia.
}

\section{Funding}

Funding was provided by Research Foundation Flanders (FWO) (Grant No. 1832817N), and Onderzoeksraad, KU Leuven (Grant Nos. STG/16/021, C24/17/070).

\section{Compliance with ethical standards}

\section{Conflicts of interest}

On behalf of both authors, the corresponding author states that there is no conflict of interest.

\section{Publisher's Note}

Springer Nature remains neutral with regard to jurisdictional claims in published maps and institutional affiliations.

Received: 21 January 2019 Accepted: 24 June 2019

Published online: 23 July 2019

\section{References}

1. Collie JTB, Greaves RF, Jones OAH, Lam Q, Eastwood GM, Bellomo R (2017) Vitamin B1 in critically ill patients: needs and challenges. Clin Chem Lab Med 55(11):1652-1668

2. Doig GS, Simpson F, Heighes PT, Bellomo R, Chesher D, Caterson ID et al (2015) Restricted versus continued standard caloric intake during the management of refeeding syndrome in critically ill adults: a randomised, parallel-group, multicentre, single-blind controlled trial. Lancet Respir Med 3(12):943-952
3. Olthof LE, Koekkoek WACK, van Setten C, Kars JCN, van Blokland D, Van Zanten ARH (2017) Impact of caloric intake in critically ill patients with, and without, refeeding syndrome: a retrospective study. Clin Nutr 37:1609-1617

4. McNamara R, Deane AM, Anstey J, Bellomo R (2018) Understanding the rationale for parenteral ascorbate (vitamin C) during an acute inflammatory reaction: a biochemical perspective. Crit Care Resusc 20(3):174-179

5. http://www.Criticalcarenutrition.com. Accessed 23 Dec 2018

6. Holick MF (2007) Vitamin D deficiency. N Engl J Med 357(3):266-281

7. Nair P, Lee P, Reynolds C, Nguyen ND, Myburgh J, Eisman JA et al (2013) Significant perturbation of vitamin D-parathyroid-calcium axis and adverse clinical outcomes in critically ill patients. Intensive Care Med 39(2):267-274

8. Amrein K, Papinutti A, Mathew E, Vila G, Parekh D (2018) Vitamin D and critical illness: what endocrinology can learn from intensive care and vice versa. Endocr Connect 7(12):R304-R315

9. Udy A, Fujii T, Luethi N (2018) What are the next steps for vitamin C in sepsis? Crit Care Resusc 20(3):172-173

10. Green R, Allen LH, Bjorke-Monsen AL, Brito A, Gueant JL, Miller JW et al (2017) Vitamin B12 deficiency. Nat Rev Dis Primers 3:17040

11. Zappitelli M, Juarez M, Castillo L, Coss-Bu J, Goldstein SL (2009) Continuous renal replacement therapy amino acid, trace metal and folate clearance in critically ill children. Intensive Care Med 35(4):698-706

12. Campillo B, Zittoun J, De GE (1988) Prophylaxis of folate deficiency in acutely ill patients: results of a randomized clinical trial. Intensive Care Med 14(6):640-645

13. Prasad AS (2012) Discovery of human zinc deficiency: 50 years later. J Trace Elem Med Biol 26(2-3):66-69

14. Livingstone C (2015) Zinc: physiology, deficiency, and parenteral nutrition. Nutr Clin Pract 30(3):371-382

15. Stefanowicz F, Gashut RA, Talwar D, Duncan A, Beulshausen JF, McMillan DC et al (2014) Assessment of plasma and red cell trace element concentrations, disease severity, and outcome in patients with critical illness. J Crit Care 29(2):214-218

16. Bonafe L, Berger MM, Que YA, Mechanick JI (2014) Carnitine deficiency in chronic critical illness. Curr Opin Clin Nutr Metab Care 17(2):200-209

17. Puskarich MA, Kline JA, Krabill V, Claremont H, Jones AE (2014) Preliminary safety and efficacy of L-carnitine infusion for the treatment of vasopressor-dependent septic shock: a randomized control trial. JPEN J Parenter Enteral Nutr 38(6):736-743 